\title{
The previously grafted forearm as a source of thin free flaps for release of neck burn contractures
}

\author{
Geoffrey G Hallock MD \\ Division of Plastic Surgery, The Lehigh Valley Hospital, Allentown, Pennsylvania
}

GG Hallock. The previously grafted forearm as a source of thin free flaps for release of neck burn contractures. Can J Plast Surg 2000;8(6):221-224.

Often, a better means to minimize recurrence after burn contracture release is by interposition of a thin, vascularized block of tissue. Such a flap should not disturb the normal contour to allow unrestricted function. If a local flap is unavailable, the forearm can be an excellent donor site for a thin free flap that also has the advantage of a long vascular pedicle. Unfortunately, in most major burn injuries, the upper extremities typically are involved and have been previously skin grafted. Nevertheless, the radial forearm free flap can be a possible option that should not be overlooked, as is demonstrated for neck resurfacing after burn contracture release. Another advantage of the radial forearm free flap is that the requisite regrafting of the forearm causes no new morbidity from an esthetic standpoint, which otherwise has been the major detriment of this donor site.

Key Words: Neck burn contractures; Radial forearm free flap

\section{Recours à un greffon de l'avant-bras comme source de lambeaux libres minces pour dégager des contractures du cou chez les grands brûlés}

RÉSUMÉ: Souvent, la meilleure façon de réduire la récurrence des contractures chez les grands brûlés consiste à interposer un bloc de tissu mince vascularisé. Ce type de lambeau ne doit pas perturber le contour normal de façon à permettre une libre mobilité. Si un lambeau local ne peut être trouvé, on peut utiliser l'avant-bras; c'est un excellent site donneur pour un lambeau libre mince et il comporte en outre l'avantage d'un long pédicule vasculaire. Malheureusement, dans la plupart des brûlures importantes, les bras sont atteints et ont déjà fait l'objet de greffes de peau. On peut par contre opter pour un lambeau libre prélevé à la face radiale de l'avant-bras. Cette technique a été utilisée pour refaire la surface du cou après libération des contractures chez un grand brûlé. Un autre avantage du lambeau libre provenant de la face radiale de l'avant-bras est que la nouvelle greffe à l'avant-bras ne provoque pas de nouvelles morbidités d'un point de vue esthétique, qui est par ailleurs le seul élément négatif de ce site donneur.

$\mathrm{M}$ odern splinting techniques have dramatically reduced but not totally eliminated the problem of burn contractures (1). Recidivism after surgical release is a universal concern directly related to problems with postoperative immobilization and patient compliance $(2,3)$. For these reasons, the Chinese, in the early 1980s, sought a single staged method that would be both a reliable and permanent solution, resulting in the introduction of the Chinese flap, now known as the radial forearm free flap (4). This Chinese flap, initially used as a vascularized flap in lieu of skin grafts after release of neck burn contractures $(2,3,5)$, has become widely accepted as a free flap or a pedicled flap for ipsilateral upper extremity flap coverage $(5,6)$. The free flap's versatility can be attributed to its consistant anatomy, large calibre nutritive vessels that simplify any microanastomoses, potential as a sensory flap using either the medial or lateral antebrachial nerves, and because it is an important source of very thin and pliable skin coverage $(2,5)$. However, the donor site defect 

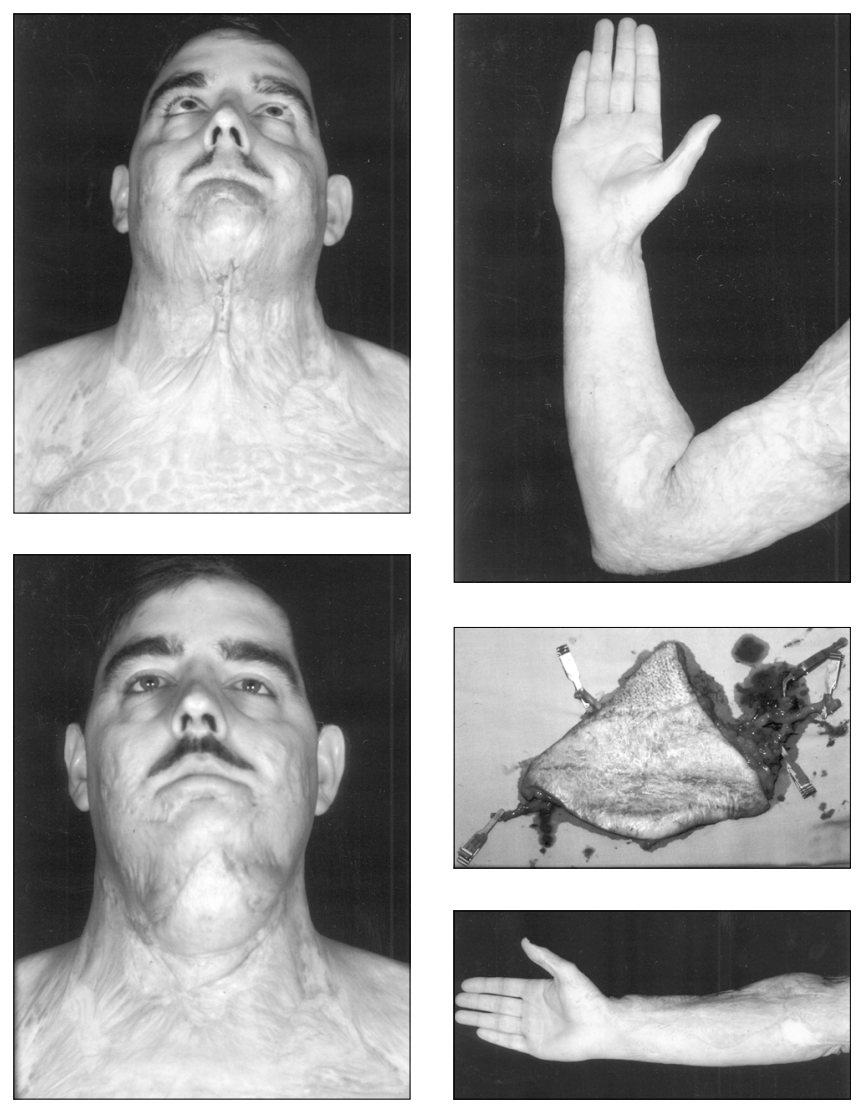

Figure 1) Top left In 1985, an anterior neck contracture band was part of the residua after skin grafting of extensive head and neck, chest, and extremity burns, Top right including the scarred and grafted volar right forearm, Middle right from which a triangular-shaped radial forearm free flap (vessels in microclamps) was cut exactly to fit the geometry of the neck defect after contracture release. Bottom left Therefore, the radial forearm free flap was successful as a thin free flap for permanent contracture release (microanastomoses were end-to-end to the facial vessels), but it left a poor cosmetic result because the esthetic neck unit was not respected (reprinted with permission from reference 5). Bottom right The regrafted forearm donor site was improved by skin recruitment during its closure

remains the major problem because the radial artery must be sacrificed and a significant contour deformity results if skin is grafted $(2,7)$. Secondary donor site problems have included unstable scars or skin grafts, flexor tendon adhesions and hand dysfunction (7).

After a major burn injury, all exposed surfaces; including the forearms, are usually concomitantly burned and often have already been skin grafted. Rather than automatically ruling out the forearm as a tissue source, it may be considered to be an even more ideal donor site. Regrafting the forearm with sheet grafts can improve the final donor site appearance. The only major prerequisite is that the original burn or wound treatment did not violate the deep forearm fascia and its vascular plexus.

\section{METHODS}

As long as the volar forearm fascia has remained intact during burn debridement and subsequent healing of any skin grafts, the perforators that arise in a segmental fashion from the deeper radial vessels will then pass via the lateral intermuscular septum between the flexor carpi radialis and brachioradialis muscles to nourish the fascial plexus of the Chinese flap (8). An Allen's test must always prove that there is sufficient ulnar artery perfusion to the hand before the radial artery can be sacrificed.

Previously burned and skin grafted territory of the radial forearm free flap has been used on two occasions by the author for resurfacing the neck after burn contracture release $(5,9)$. The open neck wound dimensions were first outlined on the volar forearm overlying the course of the palpable radial artery. Identification of the deep forearm fascia was easy by commencing from the ulnar border of the proposed flap, where this fascia is the thickest (5). Dissection below the fascia proceeded from each boundary toward the flexor carpi radialis and brachioradialis tendons before elevating the radial vessels encompassed within the lateral intermuscular septum. A distal to proximal dissection beneath the radial vessels was the easiest course, ceasing when the desired length of the vascular pedicle had been obtained. In general, because superficial forearm veins may have been destroyed by the burn or previous intravenous cannulations (9), the radial venae comitantes must be more carefully preserved than usual as they may be the only means for flap outflow. Usually a tourniquet should be used to allow a bloodless dissection, which is then deflated to verify the adequacy of flap perfusion. After isolation of appropriate recipient vessels in the neck, the flap is was transferred and microanastomoses completed by using standard techniques. Any exposed tendons in the forearm can be wrapped within the underlying sublimis muscles to facilitate successful regrafting of the donor site. Although the hand requires immobilization for several days to ensure that the skin graft takes, only minimal restrictions need be enforced for the neck. Monitoring should be per unit routine. No long term physical therapy is required.

\section{RESULTS}

In the author's experience over the past 20 years, a radial forearm free flap donor site that had a previous history of skin grafts after forearm burns was selected on only two occasions. The first time was in 1985 (Figure 1) and the second time was in 1996 (Figure 2) for two patients who both had neck burn contractures and required thin flap coverage. Both patients had had multiple attempts at contracture release at other clinics, using skin grafts with recontracture. Both patients underwent repeat neck contracture release and then immediate resurfacing using a skin grafted radial forearm free flap. Both patients regained excellent neck mobility without the need for any additional releases.

The good functional but poor esthetic result in the first case (Figure 1) reflects a lack of respect at that time for the concept of the total neck esthetic unit (10). A poor esthetic result could not be avoided in the second patient who refused to have any new skin graft donor site deformities that would result from a large free flap, nor would he allow pretransfer tissue expansion $(3,11)$. Therefore, by using his previously skin grafted forearm as a radial forearm free flap (Figure 2) was 
the best overall solution. In both cases, the 'new' skin of the neck retained the meshed appearance of the original skin grafts. The only donor site morbidity for both was a return to the pre-existing noncosmetic appearance of their forearm skin grafts.

\section{DISCUSSION}

The goals for treatment of any burn contracture are the complete release of all scar tissue, minimization of the risk of recurrence and restoration of a normal appearance $(3,12)$. Many methods suitable for mild or moderate defects include z-plasties $(1,13)$, local skin $(14,15)$ or musculocutaneous flaps (16), tissue expansion (17), and sometimes, skin grafts in ideal patients $(1,13)$. More extreme contractures, such as mentosternal adhesion involving the neck, imply an inadequate local tissue reserve and usually require more complex solutions for introducing new tissue into the defect. In such cases, a free flap may be the only reasonable alternative $(10,12,18,19)$. Previously skin grafted fasciocutaneous flaps used in burn reconstruction have proven to be reliable because the deep fascia and its vascular plexus are typically spared if debridement or tangential excision has not been overly zealous $(6,20)$. The skin grafted radial forearm flap has already been used as a local flap (6), and as demonstrated in Figures 1 and 2 also can be safely transferred as a free flap. Whether the inclusion of the deep fasica is imperative for fasciocutaneous flaps in general is debatable (20), but after a burn that has required skin grafts, it is more essential because retention of the deep fascia ensures that the overlying skin graft will not be separated accidently from whatever remains as its source of vascularization (6). Another important precaution is that the potential skin grafted donor site must have regained enough pliability to allow flexibility for flap insetting, which may not be for many months after the burn injury (20).

Because any skin grafted donor territory poorly tolerates pretransfer expansion (5), the potential surface area of a previously burned forearm cannot be expected to replace an area as large as needed for an entire esthetic neck unit (10). The skin of this flap at the recipient site, of course, will still look like the original skin graft. Because of these limitations, this choice usually is a secondary option for resurfacing exposed areas after burn contracture release. A major advantage, though is that criticism directed against the donor site defect would be deflected because the appearance of the forearm after regrafting would be no worse than that after the original injury. All factors considered, in select circumstances if a thin flap is essential, the burned and previously skin grafted forearm can still be used successfully for burn reconstruction and should not be overlooked as a potential option.

ACKNOWLEDGEMENTS: David C Rice, Advanced Clinical Technologies Department, The Lehigh Valley Hospital, Allentown, Pennsylvania, assisted with the microsurgery portion of the cases presented in this paper.
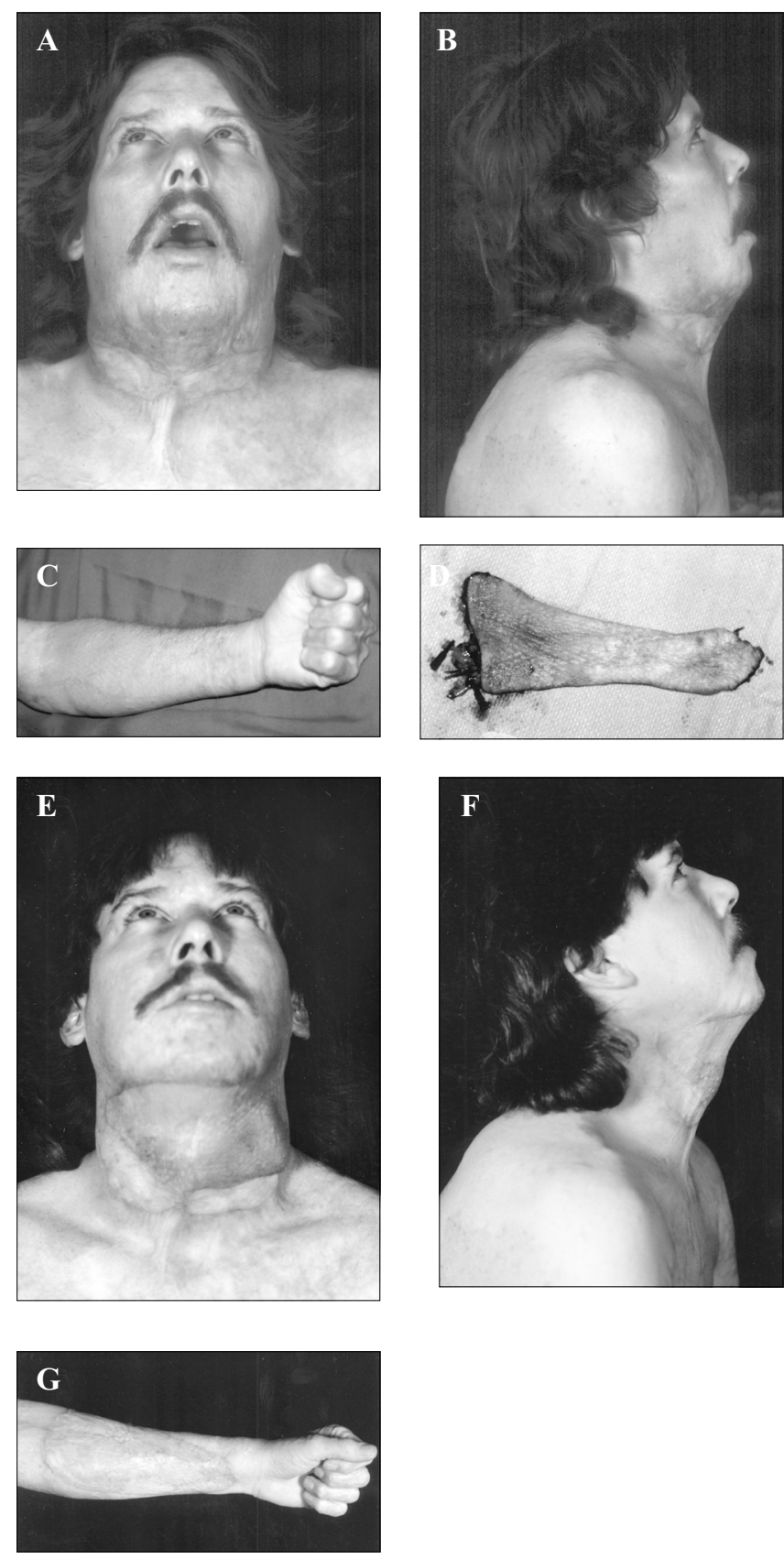

Figure 2) A,B Burns of the face and neck resulted in an anterior neck contracture with a patchwork quilt appearance after previous unsuccessful release with skin grafts. $\mathbf{C}$ Early tangential excision and meshed skin grafting of concomitant left forearm burns promoted rapid healing and assured preservation of the deep forearm fascia, so that a thin radial forearm free flap could be harvested (D), for long term functional release of the neck contracture $(\mathbf{E}, \mathbf{F})$, and improvement of the forearm donor site by sheet grafting $(\mathbf{G})$

\section{REFERENCES}

1. Achauer BM. Neck Reconstruction, Burn Reconstruction. New York: Thieme, 1991:79-86.

2. Safak T, Kayikcioglu A, Ozcan G, Kecik A. Sharing the radial forearm flap in reconstruction of two separate defects in the same patient. Ann Plast Surg 1996;36:313-5. 
3. Kenney JG, DiMercurio S, Angel M. Tissue-expanded radial forearm free flap in neck burn contracture. J Burn Care Rehab 1990;11:443-5.

4. Song R, Gao Y, Song Y, Yu Y, Song Y. The forearm flap. Clin Plast Surg 1982;9:21-6.

5. Hallock GG. The radial forearm flap in burn reconstruction. J Burn Care Rehab 1986;7:318-22.

6. Pribaz JJ, Pelham FR. Use of previously burned skin in local fasciocutaneous flaps for upper extremity reconstruction. Ann Plast Surg 1994;33:272-80.

7. Hallock GG. Refinement of the radial forearm flap donor site using skin expansion. Plast Reconstr Surg 1988;81:21-5.

8. Cormack GC, Lamberty BGH. A classification of fasciocutaneous flaps according to their patterns of vascularisation. Br J Plast Surg 1984;37:80-7.

9. Hallock GG. Caution in using the Chinese radial forearm flap. Plast Reconstr Surg 1986;77:164-5.

10. Angrigiani C. Aesthetic microsurgical reconstruction of anterior neck burn deformities. Plast Reconstr Surg 1994;93:507-18.

11. Masser MR. The preexpanded radial free flap. Plast Reconstr Surg 1990;86:295-301.
12. Ohkubo E, Kobayashi S, Sekiguchi J, Ohmori K. Restoration of the anterior neck surface in the burned patient by free groin flap. Plast Reconstr Surg 1991;87:276-84.

13. Neale HW, Billmire DA, Carey JP. Reconstruction following head and neck burns. Clin Plast Surg 1986;13:119-36.

14. Aranmolate S, Attah AA. Bilobed flap in the release of postburn mentosternal contracture. Plast Reconstr Surg 1989;83:356-61.

15. Staub S, Pugash E. Treatment of cervical burn contracture with two fasciocutaneous flaps. Ann Plast Surg 1986;17:350-2.

16. Ohba S, Inoue T, Ueda K, Takamatsu A. The pedicled, extended serratus anterior musculocutaneous flap for cervical contracture release. Ann Plast Surg 1995;35:416-9.

17. Hallock GG. Tissue expansion techniques in burn reconstruction. Ann Plast Surg 1987;18:274-82.

18. Economides NG, Ferrell TH. Neck resurfacing with free TRAM flap. Microsurg 1992;13:240-2.

19. Abramson DL, Pribaz JJ, Orgill DP. The use of free tissue transfer in burn reconstruction. J Burn Care Rehab 1996;17:402-8.

20. Hallock GG. The role of local fasciocutaneous flaps in total burn wound management. Plast Reconstr Surg 1992;90:629-35. 